\title{
Intelligent multimedia big data computing for internet of things
}

Published online: 3 September 2019

(C) Springer Science+Business Media, LLC, part of Springer Nature 2019

Multimedia Tools and Applications gratefully acknowledges the editorial work of the scholars listed below on the special issue entitled "Intelligent Multimedia Big Data Computing for Internet of Things."

Of 49 papers submitted to this issue, 38 were eventually accepted after a stringent peer-review process.

\section{Corresponding Guest Editor}

\section{Neal N. Xiong}

Northeastern State University, USA

E-mail: xiongnaixue@gmail.com

\section{Guest Editors}

Dr. Jaime Lloret Mauri.

Polytechnic University of Valencia, Spain

E-mail: jlloret@dcom.upv.es

Dr. Sajid Hussain,

Fisk University, USA

E-mail: shussain@fisk.edu

Pulisher's note Springer Nature remains neutral with regard to jurisdictional claims in published maps and institutional affiliations 